\title{
Land subsidence in Venice and Porto Corsini $\left(^{*}\right)$
}

\author{
M. Caputo - I. Pieri - F. Rossi Tesi (**)
}

Received on January 22, 1972

\begin{abstract}
Summary. - This paper is a contribution to the study of the problem of subsidence in the Po delta and in the Venetian lagoon. We have compared the data supplied by tide gauges in Trieste, Venice and Porto Corsini (Fig. 1) during the period 1896-1966, and in Genoa in the period 1894-1966. Although data were recorded in slightly different periods, these periods are sufficiently overlapping to allow for a significant statistical comparison. We note that the movement of the annual mean sea level in Genoa and Trieste is greatly different from that of Porto Corsini and Venice and, in order to separate the component due to eustatic effect from any possible movement of the coast, we calculate the polinomial coefficients, that best fit the real movements. Approximating polinomials are of first degree for Genoa and Trieste and of second degree for Porto Corsini and Venice. We have evaluate the coefficients of crosscorrelation firstly on original data and then subtracting from original data the best fit polinomials. The correlation is very significant and the trend is similar in Trieste and Genoa. The power spectrum analysis with the direct Fourier's method show long periods wich are shared by tide gauges. We conclude estimating $1.35 \mathrm{~mm} /$ year the increase of the mean sea level for the enstatic effect in the Merliterranean 3,9 mm/year the subsidence in Porto Corsini and 1,4 $\mathrm{mm} /$ year the subsidence in Venice.
\end{abstract}

Riassunto. - Allo scopo di contribuire allo studio della subsidenza nel delta padano e nella laguna veneta abbiamo confrontato i dati mareografici di Trieste, Venezia e Porto Corsini nel periodo (1896-1966) e quelli di Genova nei periodi (1884-1910) e (1928-1966). L'analisi di tali dati mostra un andamento secolare cui si sovrappongono variazioni periodiche; risulta inoltre che i movimenti del livello medio del mare a Porto Corsini e a Venezia differiscono nettamente da quelli di Genova $\theta$ Trieste che invece sono in ottimo accordo tra di loro. Abbiamo poi calcolato le linee di regressione che si adat. tano meglio ai valori osservati: tali linee risultano delle rette per Genova e Trieste e delle curve di II grado per Porto Corsini e Venezia. I coeflicienti

(*) This work has been carry out by the contribution of C.N.R. (Lavoro eseguito con il contributo del C.N.R.).

$\left.{ }^{* *}\right)$ Institute of Geodesy and Topography University of Bologna (Italy). 
di correlazione tra $\mathrm{i}$ valori originali $\theta$ tra quelli corretti per l'andamento secolare dimostrano lotıma correlazione tra i dati registrati in tutte le localitì. I'analisi spettrale. effettuata con il metodo diretto di Fourier, mostra chiaramente i seguenti periodi annui per tutti i mareografi: 20.0; $12.5 ; 8.3 ; 6.7 ; 4.0 ; 3.4$. Si conclude osservando che linnalzamento anunuo enstatico del livello medio marino nel Mediterraneo risulta di mm 1,4 nell $u l$ timo secolo, mentre la subsidenza a Porto Corsini è di mm 3,9 e, a Venezia, di $\mathrm{mm} 1,4$ annui.

\section{1. - Statemeit of tile problem}

An analysis of long time records of tide gauges located in differents stable areas should give the secular sea level variation. Unfortunatly it is not easy to prove the stability of stations where mareographs are located.

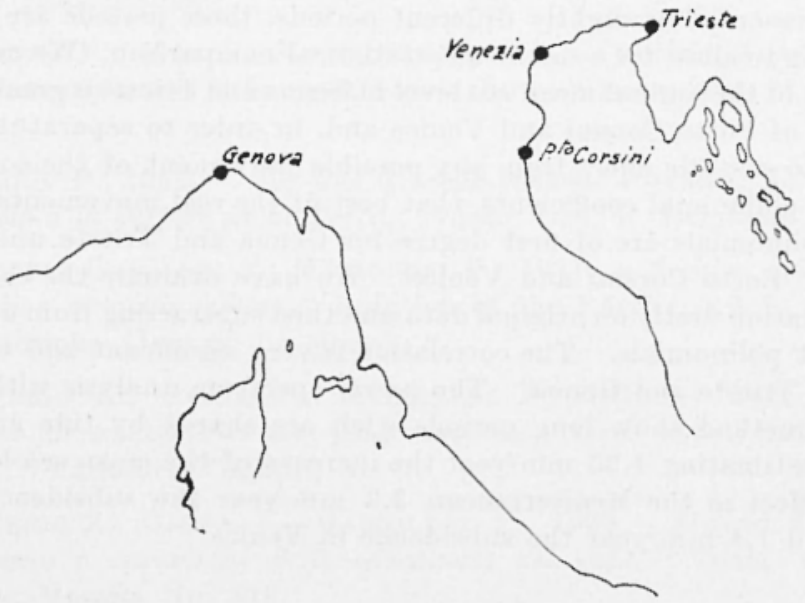

Fig 1

We have collected data on four italian stations located in geologically different areas covering about 70 years and attempted to estimate the secular variation of the sea level and also the subsidence of some of the stations. To have more accurate results the analyses of a larger number of stations should be made; however we feel that the data that we analyse give consistent and accurate results.

\section{2. - AVAILABLE DATA}

Data are supplierl by tirle gauges in Trieste, Venice, Porto Corsini and Genoa, they are yearly averages of observations carried out in the periods listed in Table 1. 
In the period 1922-1934 in Porto Corsini occasional recordings were male which allowed for an interpolation that covers the whole lapse of time 1896-1966. It was impossible to perform the same operation in Genoa, because the local tirle gauge had been damaged in the course of various war events and remained inactive between 1911 and $192 \pi$.

The tide gauges of Genoa and Trieste are located on solid rocks those of Venice and Porto Corsini are on thick serliments which are known to subside.

Table 1 summarizes the periods for which we have information.

$$
\text { Table } 1
$$

\begin{tabular}{|l|l|}
\hline Place & Period \\
\hline Trieste & $1896 \cdot 1966$ \\
\hline Venice & $1896-1966$ \\
\hline Porto Corsini & $1896-1966$ \\
\hline Genoa & $1884-1910$ \\
\hline
\end{tabular}

3. - DATA ANALYSIS.

Figs. 2, 3, 4, 5, concerning the recorded tide gauge data, clearly show that the movement of the mean annual sea levels in Porto Corsini and Venice greatly differs from that observed in Genoa and Trieste. A survey of the data suggest that in each station there is a secular trend on which periodic oscillations are placed on.

In order to separate the periodic movement of the sea level and the component due to glacial eustatic effect from the secular trend, we computed best fit polynomials of 1 st degree for Genoa and Trieste and 2nd degree for Porto Corsini and Venice.

The correlation coefficients between the raw data and the data after subtracting the secular trend are given in Tables 2 and 3 . It is 
$5 \varepsilon$

M. CAPUTO - I. PIER - F. ROSS TESI

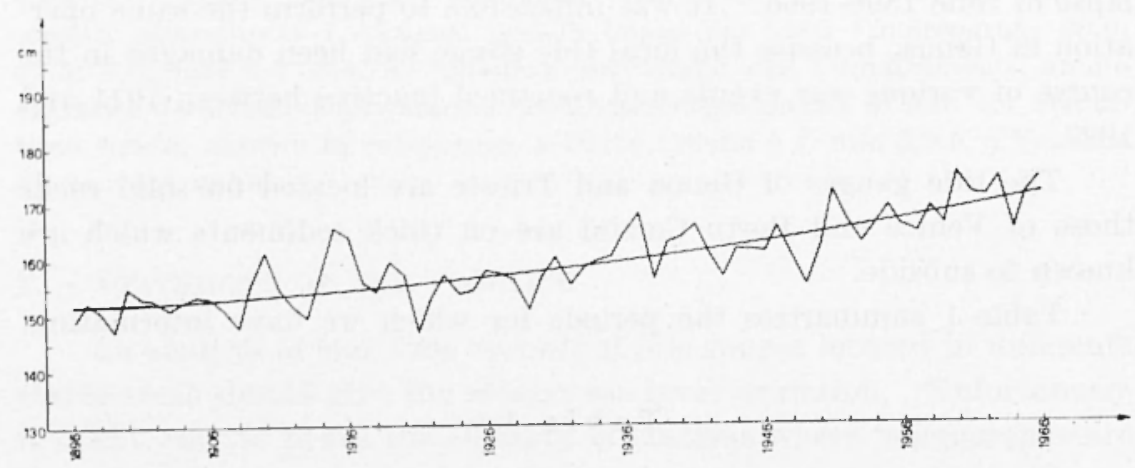

Fig. 2 - Mean annual sea level in Trieste.

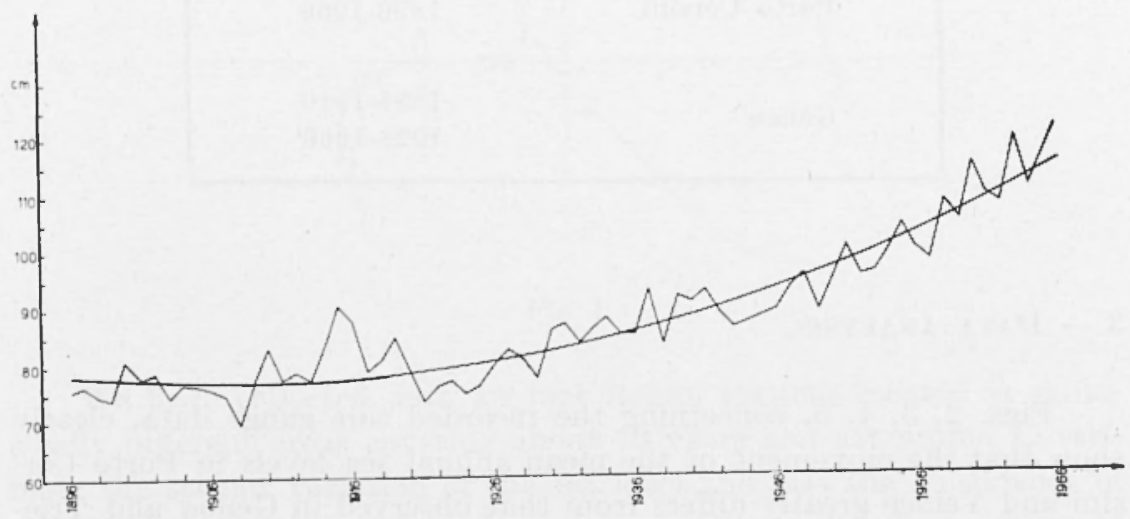

Fig. 3 - Mean annual sea level in Porto Corsini. 


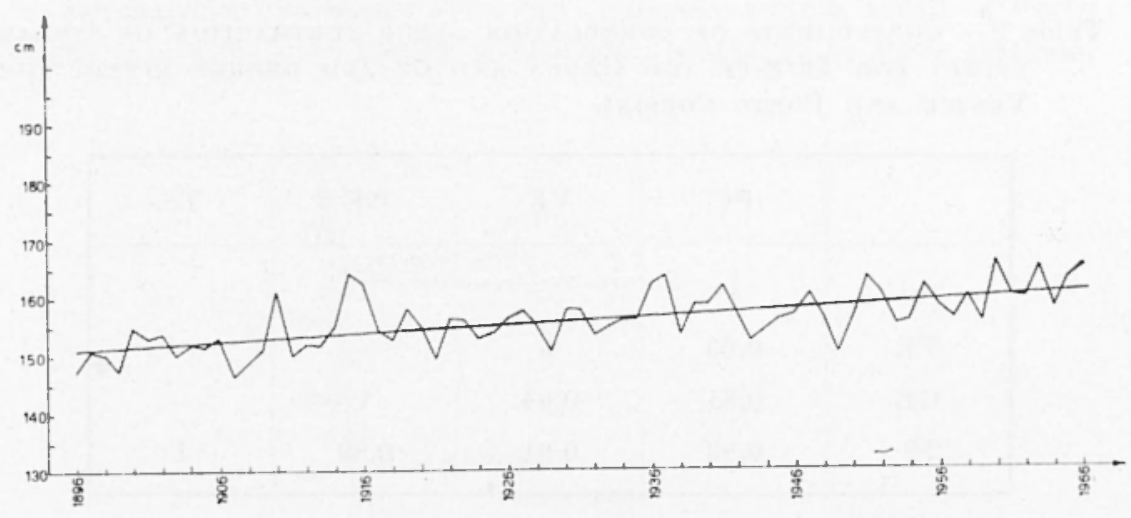

Fig. 4 - Mean annual sea level in Venice.

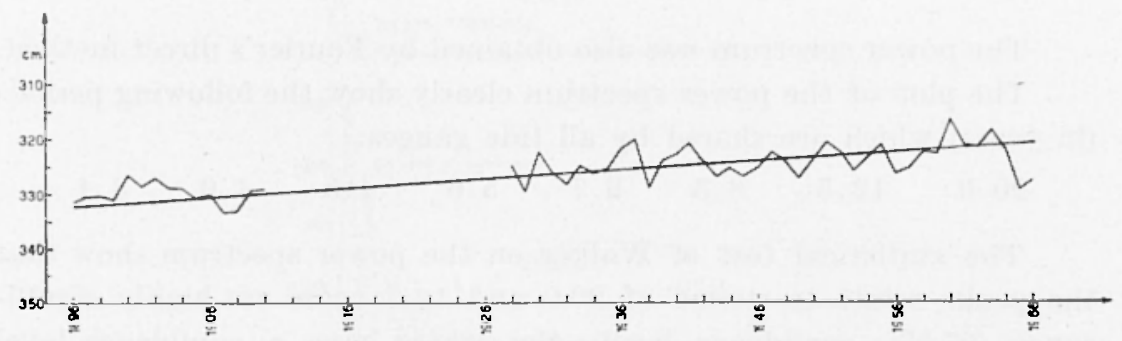

Fig. 5 - Mean annual sea level in Genova.

obvious that the correlation is very significant after removal of the secular effect which proves the physical significant of the data for the long periodic variations of the sea level.

Table 2 - Correlation COEFFICIENTS FOR THE RAW DATA

\begin{tabular}{|c|c|c|c|c|}
\hline & PC & VE & GE & TS \\
\cline { 2 - 4 } PC & 1 & - & - & - \\
VE & 0,92 & 1 & - & - \\
GE & 0,78 & 0,89 & 1 & - \\
TS & 0,75 & 0,90 & 0,91 & 1 \\
\hline
\end{tabular}


Table 3 - Coefficients of CORrelation after subtraction of i,inear

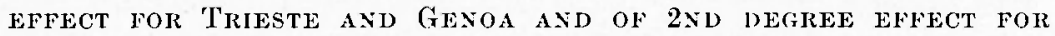
Tenice and Ponto Corsini.

\begin{tabular}{|c|c|c|c|c|}
\hline & $\mathrm{PC}$ & $\mathrm{VE}$ & $\mathrm{GE}$ & $\mathrm{TS}$ \\
\cline { 2 - 3 } $\mathrm{PC}$ & $\mathrm{I}$ & - & - & - \\
$\mathrm{VE}$ & 0,83 & 1 & - & - \\
$\mathrm{GE}$ & $0,8 \mathrm{I}$ & 0,84 & 1 & - \\
$\mathrm{TS}$ & 0,83 & 0,91 & 0,89 & 1 \\
\hline
\end{tabular}

4. - Spectral ANALYsis.

The power spectrum was also obtained by Fourier's direct methor.

The plot of the power spectrum clearly show the following periods (in years) which are shared by all tide gauges:

$$
\begin{array}{llllllll}
20.0 & 12.5 & 8.3 & 6.7 & 5.6 & 4.5 & 4.0 & 3.4
\end{array}
$$

The statistical test of Walker on the power spectrum show that the peaks relate to period of 20.0 and 12.5 years are highly significance $(97,5 \%$ confidence level); the others have a confidence level lower than $60 \%$.

It should be noted that some periods related to the Genoa recordings are slightly different from those recorded by the other tide gauges, from this it is point out also a period at 25 years which does not appear in the other records. This difference is most probably due to the different situation in the sea basins. Also the power spectrum concerning Genoa data is based on a less complete time series.

\section{5. - Secular tREnd ANALYSis.}

As we mentioned the tide gauges in Venice and Porto Corsini are located on thick sediments in areas wich are known to subside. The linear secular trend in Trieste and Genoa which are located in stable rock of geological different areas are: $1.40 \mathrm{~mm} /$ year and $1.36 \mathrm{~mm} /$ year in perfect agreement. This linear trend is very probably due to eustatic sea rise. 
Subtracting this trend from the quadratic secular trend of Porto Corsini and Venice we should obtain the subsidence in these stations;

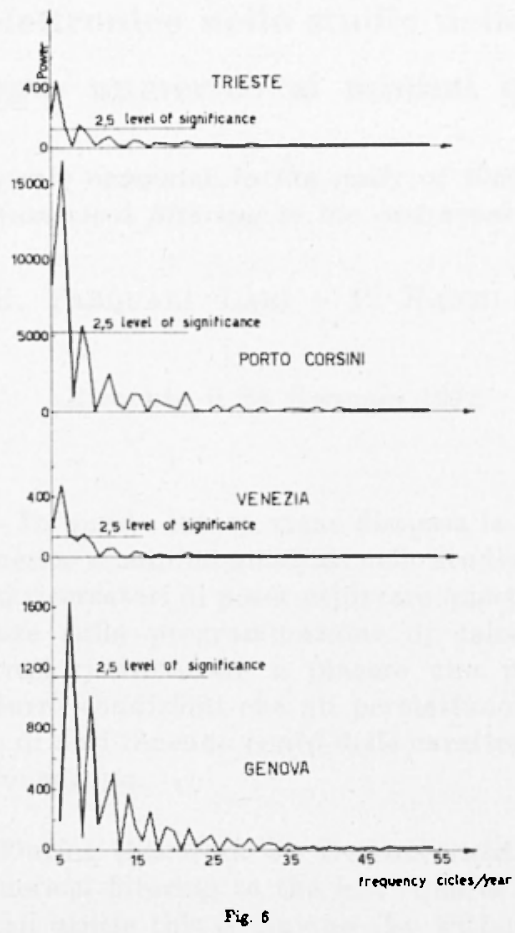

we see that the lowering of the land level during the last 70 years has had the average rate of $3.9 \mathrm{~mm} / \mathrm{year}$ in Porto Corsini and $1.4 \mathrm{~mm} / \mathrm{year}$ at the tide ganges in Venice. 